\title{
Decomposition of oroidin in DMSO/TFA
}

\author{
Thomas Lindel, ${ }^{\mathrm{a}, *}$ Gregor Breckle, ${ }^{\mathrm{a}}$ Matthias Hochgürtel, ${ }^{\mathrm{a}, \dagger}$ Christian Volk, ${ }^{\mathrm{b}}$ \\ Achim Grube ${ }^{\mathrm{b}}$ and Matthias Köck ${ }^{\mathrm{b}, *}$ \\ ${ }^{a}$ Ludwig-Maximilians-Universität, Department of Chemistry and Biochemistry, D-81377 Munich, Germany \\ ${ }^{\mathrm{b}}$ Alfred-Wegener-Institut für Polar- und Meeresforschung in der Helmholtz-Gemeinschaft, D-27570 Bremerhaven, Germany
}

Received 10 June 2004; revised 6 September 2004; accepted 7 September 2004

Available online 22 September 2004

Dedicated to Professor Axel Zeeck on the occasion of his 65th birthday

\begin{abstract}
Oxidative cyclization of the pyrrole-imidazole alkaloids oroidin and sventrin in DMSO/TFA (1:1) yields oxazolines via nucleophilic attack of the carbonyl oxygen at the alkenyl double bond. Oxidation takes place in the benzylic position of the imidazole ring. On prolonged reaction times, the oxazoline ring is hydrolyzed yielding the corresponding ester of pyrrole-2-carboxylic acid containing a free amino group. Overall, the double bond of oroidin is dioxygenated.
\end{abstract}

(c) 2004 Elsevier Ltd. All rights reserved.

\section{Introduction}

More than 90 pyrrole-imidazole alkaloids have been isolated from marine sponges. Biogenetically, they can be derived from oroidin (1, Fig. 1) and constitute one of the most fascinating families of natural products. ${ }^{1}$ The prominent position of the pyrrole-imidazole alkaloids among natural products justifies the investigation of their particular chemistry.

Key to the structural diversity of the pyrrole-imidazole alkaloids is the 2-amino-5-alkenylimidazole partial<smiles>Nc1nc(/C=C/CNC(=O)c2cc(Br)c(Br)[nH]2)c[nH]1</smiles>

1: oroidin<smiles>NC[C@H](O)[C@@H](O)c1cnc(N)[nH]1</smiles>

2: girolline
Figure 1. Structures of the natural products oroidin (1) and girolline (2) with an oxidized alkene moiety.

Keywords: Aminoimidazoles; Marine natural products; Medicinal chemistry; Oxazolines; Pyrrole-imidazole alkaloids.

* Corresponding authors. Tel.: +49 892180 77733; fax: +49 892180 77734; e-mail addresses: thomas.lindel@cup.uni-muenchen.de; mkoeck@awi-bremerhaven.de

† Present address: Alantos Pharmaceuticals AG, Im Neuenheimer Feld 584, D-69120 Heidelberg, Germany. structure of oroidin (1), which can undergo various $\mathrm{C}-$ $\mathrm{C}$ bond couplings and oxidative processes. Oxidation of the double bond of the east half of oroidin (1) is observed, for example, in the cytotoxic natural product girolline $(2)^{2}$ probably being derived from the corresponding alkene, which was also isolated as a natural product. ${ }^{3}$ Horne and co-workers have shown that the diastereomer of girolline (2) can be obtained in low yield by treatment of that alkene with NCS/TFA. ${ }^{4}$ There are also cyclized pyrrole-imidazole alkaloids with a chlorohydrin partial structure. ${ }^{5}$

In this paper we report on a hitherto unknown reaction of the key natural product oroidin (1), ${ }^{6}$ eventually leading to the dioxygenation of its double bond.

\section{Results and discussion}

For our study, oroidin (1) was isolated from various species of marine sponges of the genus Agelas. On dissolving oroidin (1) in DMSO- $d_{6} / \mathrm{TFA}-d_{1}(1: 1)$ at room temperature, the formation of two new sets of NMR signals was immediately observed. Figure 2 gives the time dependence of the decomposition of oroidin (1), which was monitored by ${ }^{1} \mathrm{H}$ NMR spectroscopy. About $50 \%$ of the starting material $\mathbf{1}$ had been consumed after 4 days. 2D NMR analysis pointed at the formation of the two diastereomeric oxazolines $\mathbf{3 a}$ and $\mathbf{3 b}$ (Scheme 1), which had reached their maximal concentrations 


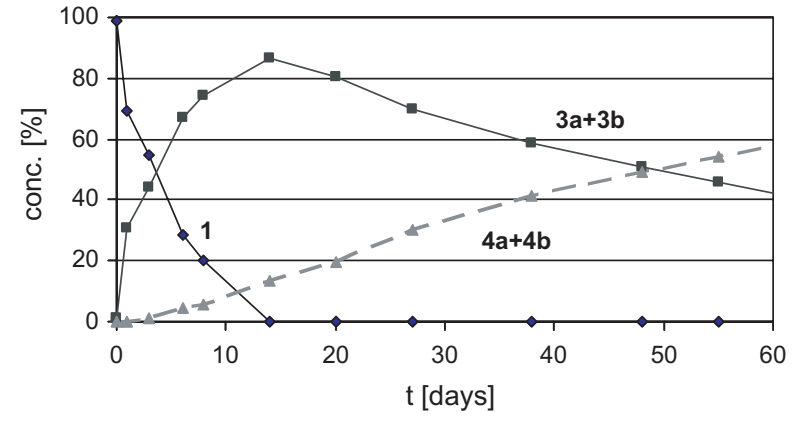

Figure 2. Time dependence of the decomposition of oroidin (1) in DMSO- $d_{6} /$ TFA- $d_{1}(1: 1)$ at room temperature. Percentages are given.

1: oroidin

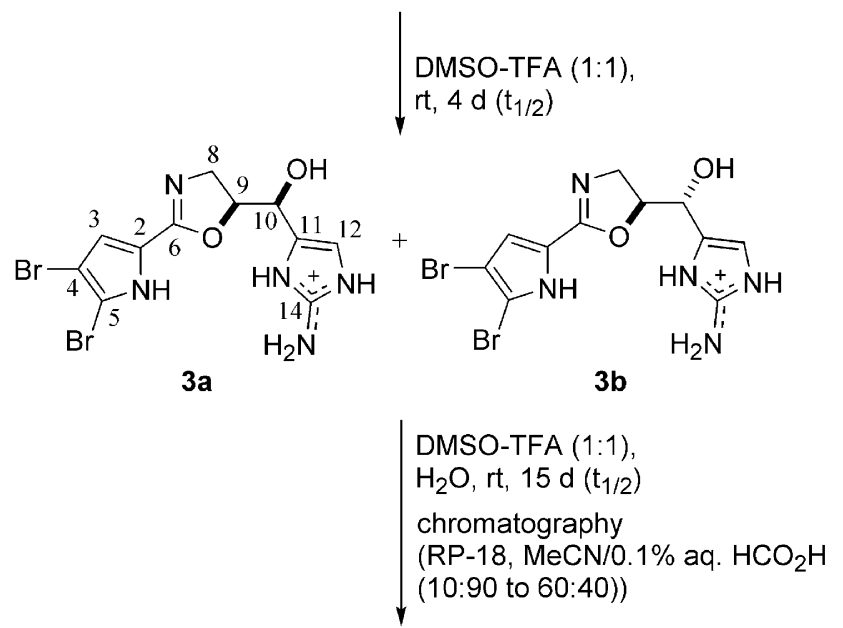<smiles>N=c1[nH]cc([C@H](O)[C@H](C[NH3+])OC(=O)c2cc(Br)c(Br)[nH]2)[nH]1</smiles>

4a

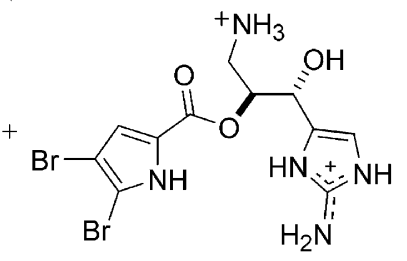

4b
Scheme 1. Decomposition of the natural product oroidin (1) in DMSO/TFA (1:1).

after 15 days. From the beginning of the experiment, growing concentrations of two additional products $\mathbf{4 a}$ and $\mathbf{4 b}$ were observed, which became dominant after about 50 days. According to 2D NMR analysis, the oxazoline ring had undergone hydrolysis of the $\mathrm{C}-\mathrm{N}$ double bond.

The HMBC correlation between 9- $\mathrm{H}$ and the carbonyl carbon C-6 was observed for each of the four compounds $3 \mathbf{a}-\mathbf{4 b}$. 9-H itself was identified as being located between the methylene group and the methine group on the basis of COSY correlations.

It was possible to determine all molecular formulae by high resolution HPLC-ESIMS (RP-18, MeCN/0.1\% aq. formic acid gradient) and to confirm that one oxygen atom was incorporated in the first step of the decompo- sition of oroidin (1). The second step indeed proceeded with incorporation of water. ${ }^{7}$

It is very difficult to conclude on the relative stereochemistry of the two diastereomers which were formed in a ratio of about 3:2. MM2 calculations indicate that for both diastereomers $\mathbf{3 a}$ and $\mathbf{3 b}$ three energetically almost equivalent minimal conformations are to be expected, which differ with regard to the respective dihedral angles between $9-\mathrm{H}$ and $10-\mathrm{H}$. For the $(9 S, 10 S)$-diastereomer 3a, the optimal dihedral angles should be about $-155^{\circ},-45^{\circ}$ and $+70^{\circ}$ (preferred by $1 \mathrm{kcal} \mathrm{mol}^{-1}$ ), while for the $(9 S, 10 R)$-diastereomer $\mathbf{3 b}$ values of about $-170^{\circ}$ (preferred by $1 \mathrm{kcal} \mathrm{mol}^{-1}$ ), $-55^{\circ}$ and $+85^{\circ}$ are to be expected. The slightly larger coupling constant ${ }^{3} J_{(9-\mathrm{H}, 10-\mathrm{H})}$ might be expected for the $(9 S, 10 R)$-diastereomer. There are only very few hydroxyalkyl oxazolines for which stereochemical and NMR assignments are available in the literature. ${ }^{8}$ Comparison supports that the larger coupling constant should be assigned to the $(9 S, 10 R)$-diastereomer $\mathbf{3 b}$.

In a parallel study, we omitted DMSO which possibly could be involved in the oxidation process. Because of the poor solubility of oroidin in chloroform, we chose to investigate the behaviour of $N$-tritylated sventrin (5, Scheme 2). ${ }^{9,10}$ When $\mathbf{5}$ was dissolved in chloroform/ TFA (5:1) at room temperature for $48 \mathrm{~h}$ under air oxygen, we observed the formation of the two diastereomeric products $\mathbf{6 a}$ and $\mathbf{6 b}(41 \%, 3: 2)$ being analogous to $3 \mathbf{a}$ and $3 \mathbf{b}$ obtained in DMSO/TFA (1:1). In addition, the ketone 7 was formed as a side product $(16 \%) .{ }^{11}$ This indicates that DMSO is not necessary to reach oxidation of $\mathrm{C}-10$. If air oxygen was excluded, no reaction took

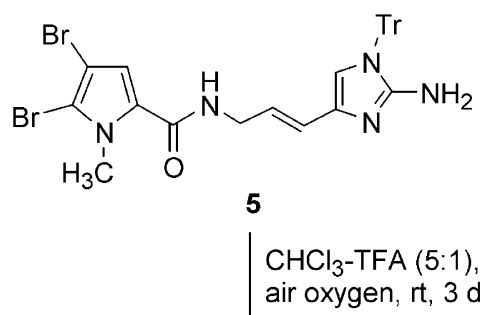
chromatography (silica, $\mathrm{CHCl}_{3} / \mathrm{MeOH} / \mathrm{NH}_{3}$ 70:10:1)<smiles>Cn1c(C2=NCC(C(O)c3cnc(N)[nH]3)O2)cc(Br)c1Br</smiles>

$6 a$<smiles>Cn1c(C2=NC[C@@H]([C@H](O)c3cnc(N)[nH]3)O2)cc(Br)c1Br</smiles>

$6 b$<smiles>Cn1c(C2=NCC(C(=O)c3cnc(N)[nH]3)O2)cc(Br)c1Br</smiles>

Scheme 2. Behaviour of $N$-methylated regioisomers: oxidative cyclization of the tritylated natural product sventrin (5) in non-degassed chloroform/TFA. 
place in chloroform. $N$-Methylation of the pyrrole ring does not have influence on the course of the oxidative oxazoline formation. The trityl group is lost under the reaction conditions. ${ }^{9}$ Compounds $6 \mathbf{6}-7$ could be purified by normal phase chromatography (silica, $\mathrm{CHCl}_{3} /$ $\mathrm{MeOH} / \mathrm{NH}_{3}$ 70:10:1) and were isolated as the free bases.

Dioxygenation of the olefinic double bond of a 2-amino-5alkenylimidazole is reported here for the first time. A possible mechanism could start with an acid-catalyzed cyclization of $\mathbf{1}$, followed by formation of a hydroperoxide at the 'benzylic' C-10, which could subsequently oxidize one additional molecule of oroidin (1) or of its cyclized oxazoline analog. Surprisingly and in contrast to $(E)$-oroidin (1), (Z)-oroidin does not undergo oxidative cyclization in DMSO/TFA (1:1). Moreover, if the imidazole ring is $N$ methylated in $o$-position to the alkyl chain both the $(Z)$ and $(E)$-isomers are stable against DMSO/TFA (1:1). By UV irradiation $(>300 \mathrm{~nm}, 400 \mathrm{~W})$, it is possible to equilibrate the natural product $(Z)$-keramadine ${ }^{12}$ with its $(E)$ isomer without decomposition (ratio $3: 1$, Scheme 2). ${ }^{13}$

Oxidative cyclization of $N$-acyl allylic amines to oxymethyl oxazolines has been observed on treatment with peroxides $^{14}$ via intermediate epoxides, and with $\mathrm{MnO}_{2}{ }^{15}$ There is a report on a similar reaction in Me$\mathrm{SO}_{3} \mathrm{H} / \mathrm{CH}_{2} \mathrm{Cl}_{2}$. ${ }^{16}$ Oxazolines derived from oroidin-type synthetic intermediates had been characterized only once by Horne et al. who treated a 5-alkenylimidazol2-one analog with $\mathrm{MeSO}_{3} \mathrm{H}$ leading to a 5-exo ring closure. ${ }^{17} \mathrm{C}-10$ was not oxidized in that case. Commerçon et al. achieved oxidation of a 1-trityl-4-alkenylimidazole with hypochlorite. ${ }^{18}$ The carbonyl oxygen which was present in an analogous position as in oroidin (1) attacked as nucleophile and the system underwent 6-endo closure to an oxazine ring.

Our study also points out that 2-amino-5-alkenylimidazoles could be critical for use in medicinal chemistry, because oxidation in the benzylic position to the imidazole ring is facile. There are only a few studies on the chemical stability of compound-TFA mixtures in DMSO. ${ }^{19}$ Kozikowski et al. found that about $50 \%$ of their compounds stored in $20 \mathrm{mM}$ DMSO solutions had decomposed after one year. ${ }^{19 b}$ However, detailed analyses of the chemistry behind these statistics are rare. ${ }^{20}$

\section{References and notes}

1. Reviews on the pyrrole-imidazole alkaloids: (a) $\mathrm{Al}$ Mourabit, A.; Potier, P. Eur. J. Org. Chem. 2001, 237; (b) Hoffmann, H.; Lindel, T. Synthesis 2003, 9, 1753.

2. Ahond, A.; Bedoya-Zurita, M.; Colin, M.; Fizames, C.; Laboute, P.; Lavelle, F.; Laurent, D.; Poupat, C.; Pusset, J.; Pusset, M.; Thoison, O.; Potier, P. C. R. Acad. Sci. Paris 1988, 307, 145.

3. Wright, A. E.; Chiles, S. A.; Cross, S. S. J. Nat. Prod. 1991, 54, 1684.

4. Olofson, A.; Yakushijin, K.; Horne, D. A. J. Org. Chem. 1997, 62, 7918.

5. Tsukamoto, S.; Tane, K.; Ohta, T.; Matsunaga, S.; Fusetani, N.; van Soest, R. W. M. J. Nat. Prod. 2001, 64, 1576.
6. (a) Forenza, S.; Minale, L.; Riccio, R.; Fattorusso, E. J. Chem. Soc., Chem. Commun. 1971, 1129; (b) Garcia, E. E.; Benjamin, L. E.; Fryer, R. I. J. Chem. Soc., Chem. Commun. 1973, 78.

7. Selected spectroscopical data of oroidin derivatives. NMR data are given in reference to the DMSO signal $\left(\delta_{\mathrm{H}} 2.50\right.$, $\left.\delta_{\mathrm{C}} 39.5\right)$. Signals of non-protonated pyrrole carbon atoms were not determined. HPLC was performed with an RP-18 stationary phase using a MeCN/0.1\% aq. formic acid gradient $(10: 90$ to $60: 40$ within $22 \mathrm{~min}, 3.0 \times 150 \mathrm{~mm}$, $3.5 \mu \mathrm{m}$, flow rate $0.25 \mathrm{ml} / \mathrm{min}, 20^{\circ} \mathrm{C}$; retention times: $3 \mathbf{a}$ $6.3 \mathrm{~min}, 3 \mathbf{b} 7.1 \mathrm{~min}, \mathbf{4 a} / \mathbf{b} 13.0 \mathrm{~min})$. NMR spectra were taken in DMSO- $d_{6} /$ TFA- $d_{1}(1: 1)$. HPLC was performed with an RP-18 stationary phase using an acetonitrile/ formic acid gradient. 3a/b: data set 1: ${ }^{1} \mathrm{H}$ NMR $(400 \mathrm{MHz}): \delta=7.32(\mathrm{~s}, 1 \mathrm{H}, 3-\mathrm{H}), 6.58\left(\mathrm{~d},{ }^{4} J=0.7 \mathrm{~Hz}\right.$, $1 \mathrm{H}, 12-\mathrm{H}), 5.38(\mathrm{~m}, 1 \mathrm{H}, 9-\mathrm{H}), 4.75\left(\mathrm{~d},{ }^{3} \mathrm{~J}=2.2 \mathrm{~Hz}, 1 \mathrm{H}, 10-\right.$ $\mathrm{H}), 4.08(\mathrm{~m}, 2 \mathrm{H}, 8-\mathrm{H}) .{ }^{13} \mathrm{C}$ NMR $(100 \mathrm{MHz}): \delta=163.8(\mathrm{C}-$ 6), 149.8 (C-14), 126.6 (C-11), 125.4 (C-3), 112.2 (C-12), 89.0 (C-9), 66.6 (C-10), 48.5 (C-8). MS (HPLC-HRESIMS): $\quad m / z=404 / 406 / 408 \quad \mathrm{C}_{11} \mathrm{H}_{12}{ }^{79} \mathrm{Br}_{2} \mathrm{~N}_{5} \mathrm{O}_{2} \quad[\mathrm{M}+\mathrm{H}]^{+}$, calcd: 403.9352; found: 403.9345. Data set 2: ${ }^{1} \mathrm{H}$ NMR (400 MHz): $\delta=7.26(\mathrm{~s}, 1 \mathrm{H}, 3-\mathrm{H}), 6.64$ (br s, 1H, 12-H), $5.40(\mathrm{~m}, 1 \mathrm{H}, 9-\mathrm{H}), 4.91\left(\mathrm{~d},{ }^{3} \mathrm{~J}=3.8 \mathrm{~Hz}, 1 \mathrm{H}, 10-\mathrm{H}\right), 4.03(\mathrm{~m}$, 2H, 8-H). ${ }^{13} \mathrm{C}$ NMR (100 MHz): $\delta=163.7$ (C-6), 149.7 (C14), 125.9 (C-11), 125.3 (C-3), 112.3 (C-12), 87.9 (C-9), 66.5 (C-10), 47.1 (C-8). MS (HPLC-HRESIMS): $\mathrm{m} /$ $z=404 / 406 / 408 \quad \mathrm{C}_{11} \mathrm{H}_{12}{ }^{79} \mathrm{Br}_{2} \mathrm{~N}_{5} \mathrm{O}_{2} \quad[\mathrm{M}+\mathrm{H}]^{+}$, calcd: 403.9352; found: 403.9341. 4a/b: NMR data were determined by 2D experiments. Data set 1: ${ }^{1} \mathrm{H}$ NMR $(400 \mathrm{MHz}): \delta=6.83(\mathrm{~s}, 1 \mathrm{H}, 3-\mathrm{H}), 6.44(\mathrm{~s}, 1 \mathrm{H}, 12-\mathrm{H})$, $5.24(\mathrm{~m}, 1 \mathrm{H}, 9-\mathrm{H}), 4.86\left(\mathrm{~d},{ }^{3} J=3.1 \mathrm{~Hz}, 1 \mathrm{H}, 10-\mathrm{H}\right), 3.22(\mathrm{~m}$, $2 \mathrm{H}, 8-\mathrm{H}) .{ }^{13} \mathrm{C}$ NMR $(100 \mathrm{MHz}):=159.5(\mathrm{C}-6), 149.4(\mathrm{C}-$ 14), 127.5 (C-11), 120.8 (C-3), 111.4 (C-12), 72.9 (C-9), 67.5 (C-10), 42.0 (C-8). Data set 2: ${ }^{1} \mathrm{H}$ NMR (400 MHz): $\delta=6.82(\mathrm{~s}, 1 \mathrm{H}, 3-\mathrm{H}), 6.50(\mathrm{~s}, 1 \mathrm{H}, 12-\mathrm{H}), 5.13(\mathrm{~m}, 1 \mathrm{H}, 9-$ $\mathrm{H}), 4.79\left(\mathrm{~d},{ }^{3} J=5.1 \mathrm{~Hz}, 1 \mathrm{H}, 10-\mathrm{H}\right), 3.21(\mathrm{~m}, 2 \mathrm{H}, 8-\mathrm{H}) .{ }^{13} \mathrm{C}$ NMR (100 MHz): $\delta=159.2(\mathrm{C}-6), 149.6(\mathrm{C}-14), 127.1$ (C11), 117.8 (C-3), 111.9 (C-12), 73.2 (C-9), 67.2 (C-10), 40.9 (C-8). MS (HPLC-HRESIMS, mixture of diastereomers not fully separated): $m / z=422 / 424 / 426 \mathrm{C}_{11} \mathrm{H}_{14}{ }^{79} \mathrm{Br}_{2} \mathrm{~N}_{5} \mathrm{O}_{3}$ $[\mathrm{M}+\mathrm{H}]^{+}$, calcd: 421.9458; found: 421.9468 .

8. (a) Murakami, T.; Taguchi, K. Tetrahedron 1999, 55, 989; (b) Suga, H.; Fujieda, H.; Hirotsu, Y.; Ibata, T. J. Org. Chem. 1994, 59, 3359.

9. Breckle, G.; Polborn, K.; Lindel, T. Z. Naturforsch., B: Chem. Sci. 2003, 58b, 451.

10. Assmann, M.; Zea, S.; Köck, M. J. Nat. Prod. 2001, 64, 1593.

11. Selected spectroscopical data of sventrin derivatives. NMR spectra were taken in methanol- $d_{4}$. $\mathbf{6 a} / \mathbf{b}$ : NMR data set $1:{ }^{1} \mathrm{H}$ NMR $(400 \mathrm{MHz}): \delta=6.90(\mathrm{~s}, 1 \mathrm{H}, 3-\mathrm{H}), 6.58$ $\left(\mathrm{d},{ }^{4} J=0.6 \mathrm{~Hz}, 1 \mathrm{H}, 12-\mathrm{H}\right), 4.87(\mathrm{~m}, 1 \mathrm{H}, 9-\mathrm{H}), 4.52(\mathrm{dd}$, $\left.{ }^{3} J=6.4 \mathrm{~Hz},{ }^{4} J=0.6 \mathrm{~Hz}, 1 \mathrm{H}, 10-\mathrm{H}\right), 3.94\left(\mathrm{dd},{ }^{2} J=14.8 \mathrm{~Hz}\right.$, $\left.{ }^{3} J=5.3 \mathrm{~Hz}, 1 \mathrm{H}, 8-\mathrm{H}_{\mathrm{a}}\right), 3.77\left(\mathrm{dd},{ }^{2} J=14.8 \mathrm{~Hz},{ }^{3} J=7.5 \mathrm{~Hz}\right.$, $\left.1 \mathrm{H}, 8-\mathrm{H}_{\mathrm{b}}\right), 3.91\left(\mathrm{~s}, 3 \mathrm{H}, \mathrm{NCH}_{3}\right) .{ }^{13} \mathrm{C} \mathrm{NMR}(100 \mathrm{MHz})$ : $\delta=158.7$ (C-6), 151.1 (C-14), 133.0 (C-11), 123.8 (C-2), 117.8 (C-3), 113.3 (C-12), 112.1 (C-5), 99.4 (C-4), 82.5 (C9), $70.0(\mathrm{C}-10), 57.5(\mathrm{C}-8), 36.7\left(\mathrm{NCH}_{3}\right)$. NMR data set 2: ${ }^{1} \mathrm{H}$ NMR (400 MHz): $\delta=6.81(\mathrm{~s}, 1 \mathrm{H}, 3-\mathrm{H}), 6.53(\mathrm{~d}$, $\left.{ }^{4} J=0.9 \mathrm{~Hz}, 1 \mathrm{H}, 12-\mathrm{H}\right), 4.87(\mathrm{~m}, 1 \mathrm{H}, 9-\mathrm{H}), 4.74(\mathrm{dd}$, $\left.{ }^{3} J=4.0 \mathrm{~Hz},{ }^{4} J=0.9 \mathrm{~Hz}, 1 \mathrm{H}, 10-\mathrm{H}\right), 4.0\left(\mathrm{~m}, 2 \mathrm{H}, 8-\mathrm{H}_{2}\right)$, $3.90\left(\mathrm{~s}, 3 \mathrm{H}, \mathrm{NCH}_{3}\right) .{ }^{13} \mathrm{C}$ NMR $(100 \mathrm{MHz}): \delta=158.69(\mathrm{C}-$ 6), 150.91 (C-14), 138.37 (C-11), 123.88 (C-2), 117.64 (C3), 112.51 (C-12), 112.05 (C-5), 99.34 (C-4), 81.99 (C-9), 69.10 (C-10), $55.97(\mathrm{C}-8), 36.63\left(\mathrm{NCH}_{3}\right)$. Mixture of diastereomers: $\mathrm{MS}(\mathrm{FAB}+, \mathrm{NBA}): m / z(\%)=418 / 420 / 422$ $(34 / 62 / 33)[\mathrm{M}+\mathrm{H}]^{+}$. HRFABMS $\left(\mathrm{C}_{12} \mathrm{H}_{14}{ }^{79} \mathrm{Br}^{81} \mathrm{BrN}_{5} \mathrm{O}_{2}\right.$ $\left.[\mathrm{M}+\mathrm{H}]^{+}\right)$calcd: 419.9494; found: 419.9465. Compound 7: ${ }^{1} \mathrm{H}$ NMR $(400 \mathrm{MHz}): \delta=7.67(\mathrm{~s}, 1 \mathrm{H}, 12-\mathrm{H}), 6.92(\mathrm{~s}, 1 \mathrm{H}$, 
3-H), $5.42\left(\mathrm{dd},{ }^{3} J=10.8,7.1 \mathrm{~Hz}, 1 \mathrm{H}, 9-\mathrm{H}\right), 4.37$ (dd, $\left.{ }^{2} J=14.8 \mathrm{~Hz}, \quad{ }^{3} J=10.8 \mathrm{~Hz}, \quad 1 \mathrm{H}, \quad 8-\mathrm{H}_{\mathrm{a}}\right), \quad 4.18 \quad(\mathrm{dd}$, $\left.{ }^{2} J=14.8 \mathrm{~Hz},{ }^{3} J=7.1 \mathrm{~Hz}, 1 \mathrm{H}, 8-\mathrm{H}_{\mathrm{b}}\right), 3.99$ (s, 3H, $\left.\mathrm{NCH}_{3}\right)$. ${ }^{13} \mathrm{C}$ NMR $(100 \mathrm{MHz}): \delta=185.1(\mathrm{C}-10), 157.4(\mathrm{C}-6), 154.3$ (C-14), 126.7 (C-11), 122.3 (C-2), 117.7 (C-3), 112.6 (C-5), 109.4 (C-12), 99.2 (C-4), 78.8 (C-9), 59.8 (C-8), 36.5 $\left(\mathrm{NCH}_{3}\right) . \mathrm{MS}(\mathrm{FAB}+, \mathrm{NBA}): m / z(\%)=416 / 418 / 420(23 /$ $42 / 22)[\mathrm{M}+\mathrm{H}]^{+}$. HRFABMS $\left(\mathrm{C}_{12} \mathrm{H}_{12}{ }^{79} \mathrm{Br}^{81}-\mathrm{BrN}_{5} \mathrm{O}_{2}\right.$ $[\mathrm{M}+\mathrm{H}]^{+}$) calcd: 417.9338 , found 417.9327 .

12. (a) Nakamura, H.; Ohizumi, Y.; Kobayashi, J. Tetrahedron Lett. 1984, 25, 2475; (b) Cafieri, F.; Fattorusso, E.; Taglialatela-Scafati, O. J. Nat. Prod. 1998, 61, 122; Synthesis according to: (c) Lindel, T.; Hochgürtel, M. Tetrahedron Lett. 1998, 39, 2541; See also: (d) DaninosZeghal, S.; Al Mourabit, A.; Ahond, A.; Poupat, C.; Potier, P. Tetrahedron 1997, 53, 7605.

13. Lindel, T.; Hochgürtel, M. J. Org. Chem. 2000, 65, 2806.

14. (a) Roush, W. R.; Straub, J. A.; Brown, R. J. J. Org. Chem. 1987, 52, 5127; (b) Tiecco, M.; Testaferri, L.; Tingoli, M. Tetrahedron 1993, 49, 5351.
15. Buddrus, J.; Defoin, A.; Krueger, C.; Tsay, Y. H.; Kuhn, H. J. Liebigs Ann. Chem. 1989, 1075.

16. McCombie, S. W.; Nagabhushan, T. L. Tetrahedron Lett. 1987, 28, 5395.

17. Sosa, A. C. B.; Yakushijin, K.; Horne, D. A. Org. Lett. 2000, 2, 3443 .

18. (a) Commerçon, A.; Ponsinet, G. Tetrahedron Lett. 1990 , 31, 3871; (b) Commerçon, A.; Guérémy, C. Tetrahedron Lett. 1991, 32, 1419.

19. (a) Hochlowski, J.; Cheng, X.; Sauer, D.; Djuric, S. J. Comb. Chem. 2003, 5, 345; (b) Kozikowski, B. A.; Burt, T. M.; Tirey, D. A.; Williams, L. E.; Kuzmak, B. R.; Stanton, D. T.; Morand, K. L.; Nelson, S. L. J. Biomol. Screening 2003, 8, 205.

20. Martin, G. E.; Hadden, C. E.; Russell, D. J.; Kaluzny, B. D.; Guido, J. E.; Duholke, W. K.; Stiemsma, B. A.; Thamann, T. J.; Crouch, R. C.; Blinov, K.; Elyashberg, M.; Martirosian, E. R.; Molodtsov, S. G.; Williams, A. J.; Schiff, P. L., Jr. J. Heterocycl. Chem. 2002, 39, 1241. 